\title{
Czech Film in Exile (Český film v exilu)
}

\author{
By Jan Uhde
}

Fall 2005 Issue of KINEMA

\begin{abstract}
CZECH FILM IN EXILE (ČESKÝ FILM V EXILU). Jiří Voráč. Brno, Host 2004. 192pp, stills, index, English summary. ISBN: 8072941399.
\end{abstract}

In Czech Film In Exile, Jiř́ Voráč turns to a topic painfully relevant for the cultural history of his country, yet ignored by his compatriot researchers for years. In the stifling times of the pre-1989 Communist dictatorship, the subject of the exile culture was strictly taboo. More surprising was that it continued to be neglected for almost fifteen years after the "velvet revolution" and subsequent democratization. Among the reasons may have been the geographic fragmentation, linguistic diversity and disorganization of the sources which had to be researched in countries on several continents. Another factor may have been a sort of ideological inertia among some of the Czech academic community, which did not seem to consider its own film exile a worthwhile academic subject.

For Voráč, a film historian at Brno's Masaryk University, the question of film exile, which included directors such as Miloš Forman, Ivan Passer, Vojtěch Jasný and Emil Radok, has been of ample significance. His wellresearched book offers a summary of the inter-war migration, the WWII and the post-1948 emigration waves. Its focus is on the post-invasion (1968) exile, the most numerous and also most productive one. He examines all of its main branches: Europe, North America and Australia. Besides the feature fiction, documentary, animated and TV productions are also discussed. The very centre of Voráč's attention are the films of Forman, Passer and Jasný. Particularly commendable is the author's inclusion of the Czech community TV in exile, which was especially active in Canada, and whose activities included the first Czech-language TV performance of Václav Havel's satirical play Audience in 1979, then still banned by the Communist regime. Voráč's history of the Czech film exile no doubt represents a valuable contribution to the Czech historiography of cinema.

\section{Author Information}

Jan UHDE is Professor Emer. (Film Studies) at the University of Waterloo, Ontario, Canada. Born in Brno, Czech Republic. Graduated (MA) from the Faculty of Arts, Masaryk University, Brno; PhD received at the University of Waterloo, Ontario, Canada. He taught at the University of Waterloo (1970-2012) where he founded a General and Honours BA program in Film Studies at the Department of Fine Arts.

Publications: Latent Images: Film in Singapore Second edition, with Yvonne Ng Uhde (Ridge Books, National University Press of Singapore, 2010); Latent Images: Film in Singapore, with Yvonne Ng Uhde (Oxford University Press, 2000); Latent Images: Film in Singapore CD-ROM (2003, co-author); Vision and Persistence: Twenty Years of the Ontario Film Institute (University of Waterloo Press, 1990) and Ontario Film Institute Programming Activities Index 1969-1989 (Toronto: Ontario Science Centre, 1990). He co-edited the Place in Space: Human Culture in Landscape (Proceedings from the Second International Conference of the Working Group "Culture and Landscape" of the International Association of Landscape Ecology, Pudoc Scientific Publishers, Wageningen, Holland, 1993). Jan Uhde has published articles and reviews in several countries (including Canada, USA, Germany, Italy), participated in international juries at film festivals and presented papers at international conferences in North America and Europe. In 1998/99, he was a visiting researcher at the School for Film and Media Studies, Ngee Ann Polytechnic, Singapore.

His professional and research interests focus on Singapore cinema; the identification and distancing mechanisms of the film viewer; the non-authored modifications and manipulation of films; and specific aspects of film history, including the Central European cinema.

He founded KINEMA in 1993. 